\title{
Simulasi dan Analisis Transmisi Multihop Mobile WiMAX Dengan Metode Hybrid
}

\section{Simulation and Analysis of Multihop Transmission for Mobile WiMAX Using Hybrid Method}

\author{
Muhamad Asvial dan Taufiq Nugroho \\ Departemen Teknik Elektro, Fakultas Teknik, Universitas Indonesia \\ Depok 16424, Indonesia
}

\begin{abstract}
Abstrak
Makalah ini membahas tentang pengembangan relay station untuk transmisi downlink Mobile WiMAX dengan menggunakan metode hybrid, yaitu metode transmisi yang menggunakan tiga buah transmisi. Ketiga transmisi tersebut yaitu dua buah transmisi yang melewati relay station terlebih dahulu baru ke receiver dan satu buah transmisi langsung dari pengirim ke penerima. Pada relay station ada dua kondisi yang berlaku, yaitu Decode and Forward (DF) dan Amplify and Forward (AF). Hasil simulasi menunjukkan bahwa ketika Relay Station dalam mode forwarding Amplify and Forward (AF) akan memperoleh BER yang kecil sehingga throughput besar dan merupakan perfomansi yang terbaik. Ketika masing-masing relay station diatur agar menggunakan mode forwarding yang berbeda, misalnya AF pada relay station 1 dan DF pada Relay Station 2 atau sebaliknya akan memperoleh hasil yang sama. Sedangkan ketika kedua relay station diatur untuk menggunakan mode forwarding Decode and Forward (DF), maka BER yang dihasilkan besar dan throughput-nya pun kecil, dan kondisi ini merupakan yang terburuk.
\end{abstract}

Kata kunci: multihop mobile WiMAX, relay station, metode hybrid.

\section{Abstract}

This paper discusses a developing of relay station for Mobile WiMAX downlink transmission using the hybrid method - the transmission method that uses three transmissions. All of the three transmissions where the two transmission pass through the relay station first before to the receiver and one transmission from the transmitter directly passes to the receiver. At the relay station there are two conditions that apply, the Decode and Forward (DF) and Amplify and Forward (AF). Simulation results show that when both relay station in Amplify and Forward (AF) forwarding mode, they will yield low BER so that the throughput will high and this state is the best performance. When both of relay station are arranged to activate different forwarding mode, for example $A F$ in relay station 1 and DF in relay station 2 or the other way, they will yield the same results. When both of relay station are arranged to activate Decode and Forward $(D F)$ forwarding mode, BER will high and throughput will low, and this condition is the worst.

Keywords: multihop mobile WiMAX, relay station, hybrid method.

\section{Pendahuluan}

Perkembangan teknologi telekomunikasi wireless khususnya untuk akses internet yang merupakan pengembangan teknologi WiFi dikenal dengan WiMAX. Teknologi ini diyakini mampu menjawab kebutuhan konsumen yang amat besar dan dinamis [1] [3]. Teknologi ini terus berkembang dan dewasa ini banyak menggunakan teknologi multihop mobile WiMAX dengan beragam pemodelan untuk mendapatkan unjuk kerja tertentu [4]. Banyak standar yang dikembangakan dan salah satunya adalah menggunakan hardware berupa multi antenna [5] - [7]. Teknologi akan sulit digunakan dengan kompleksitas dan efisiensi biaya yang cukup tinggi. Oleh karena itu, banyak dilakukan pengembangan dari sisi software dengan mengembangkan protokol-protokol pada layer 2

\footnotetext{
* Corresponding Author.

Email: asvial@eng.ui.ac.id

Received: April 16, 2014; Revised: June 6, 2014

Accepted: June 27, 2014

Published: June 30, 2014

(C) 2014 PPET - LIPI

doi : $10.14203 /$ jet.v14.8-14
}

dan 3 berdasarkan format OSI layer yang lebih dikenal dengan MAC layer [8], [9]. Ada juga teknologi yang dikembangakan dengan mengadopsi penggunaan relay.

Penerapan multihop mobile WiMAX ini dilakukan dengan penambahan komponen pada WiMAX konvensional, yaitu relay station. Komponen ini dapat bertindak selayaknya amplifier maupun sebagai BTS. Penambahan ini memberikan keuntungan, yaitu bertambahnya kapasitas dan bertambah luasnya coverage.

Penggunaan relay station di sini menggunakan dua buah mode forwarding, yaitu Amplify and Forward (AF) dan Decode and Forward (DF). Mode-mode ini diperkenalkan dalam United States Patent Application Publication [10]. Pada patent ini dijelaskan mengenai skema pemilihan penggunaan mode forwarding AF dan DF.

Dalam mentransmisikan data, metode transmisi dengan bantuan relay station ini pun ada bermacammacam. Salah satunya yaitu dengan menggunakan metode hybrid. Metode inilah yang akan disimulasikan dan dianalisis unjuk kerjanya. Metode ini penulis 
ketahui dalam suatu presentasi yang dibawakan oleh Pusan National University.

Hasil dari simulasi ini menjelaskan bahwa metode hybrid dapat digunakan dalam mentransmisikan data dengan performa yang baik. Selain itu, mode forwarding pada masing-masing Relay Station sebaiknya berbeda atau kalau pun sama, hanya mode forwarding Amplify and Forward (AF) saja. Apabila mode forwarding yang digunakan pada masing-masing Relay Station sama, yaitu Decode and Forward (DF), maka sistem dipastikan akan memperoleh loss yang sangat besar, sesuai yang dijelaskan pada simulasi ini.

\section{SISTEM TRANSMISI}

\section{A. AMC}

Kebutuhan akan kemudahan dalam komunikasi menyebabkan perlunya perancangan suatu sistem komunikasi yang jauh lebih pintar dan cepat, yang mampu menghasilkan akses data yang fleksibel dan efisien. Karena itu, terdapat suatu sistem AMC yang dapat beradaptasi dan mengatur parameter transmisi berdasarkan kualitas link yang dapat memberikan efisiensi spektrum terhadap sistem.

AMC didesain untuk bekerja pada kanal yang bervariasi, dimana AMC dapat mengubah skema modulasi dan coding yang digunakan sehingga menghasilkan throughput yang lebih besar dengan mentransmisikan data dengan modulasi yang memberikan data rate yang tinggi pada saat kondisi kanal transmisi sedang baik dan mentransmisikan data dengan modulasi yang menghasilkan error yang kecil pada saat kondisi kanal buruk.

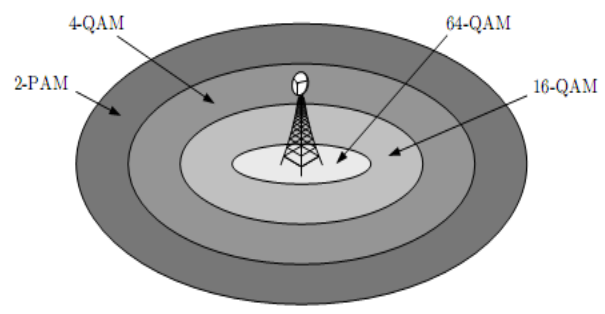

Gambar 1. Pembagian Daerah Kerja pada AMC.

Pada Gambar 1 terlihat bahwa pada wilayah yang jauh dari pemancar sehingga memiliki kualitas kanal yang buruk, digunakan modulasi yang menghasilkan error kecil. Namun, pada wilayah yang dekat dengan pemancar digunakan modulasi yang menghasilkan data rate yang tinggi.

\section{B. STBC/MIMO Matriks A}

MIMO Matrix A menggunakan space-time coding (STC), meningkatkan realibilitas transmisi data untuk mobile modem, dan menggunakan transmisi multiple antenna. Sebuah cell site MIMO berakhir menjadi berlipat ganda, salinan data stream yang redundan ke penerima untuk meningkatkan kemungkinan bahwa beberapa dari data tersebut bertahan dari physical path antara transmisi dan penerimaan dalam keadaan cukup baik untuk memungkinkan decoding yang reliable. Redundansi ini ada pada ruang (dengan menggunakan beberapa antena), dan waktu.
Kondisi ini sangat mungkin terjadi saat terminal sangat mobile, dengan rapid signal fading dan penerimaan multipath. Dengan menambahkan redundan, path paralel, modem telah memiliki dua kali kesempatan untuk menerima salinan data yang bagus. Di bawah kondisi normal stabil (stationary), gain yang diberikan oleh STC hanya $+3 \mathrm{~dB}$, tetapi dalam lingkungan fading, seperti ketika melewati antara bangunan dengan cepat, gain yang dapat diperoleh sebanyak $5 \mathrm{~dB}$ untuk 16-QAM dB dan $+10 \mathrm{~dB}$ untuk 64-QAM (dibandingkan dengan sinyal non-STC di bawah kondisi yang sama)[7]. Hasilnya adalah bahwa sistem dapat menghasilkan throughput yang relatif tinggi di bawah kondisi sulit.

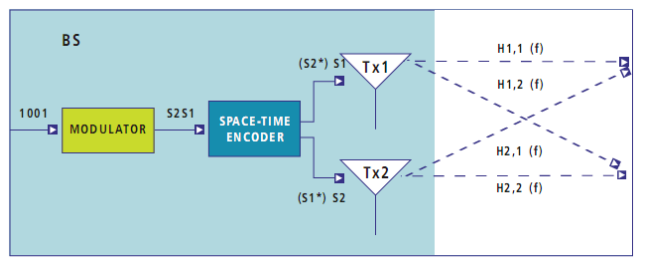

Gambar 2. Prinsip Kerja MIMO Matrix A.

Jika simbol yang ditransmisikan adalah $x_{1}$ dan $x_{2}$, maka setelah $x_{1}$ dan $x_{2}$ ditransmisikan dan tercampur dengan noise maka persamaan sinyal yang diterima di receiver adalah sebagai berikut :

$$
\begin{aligned}
& {\left[\begin{array}{l}
y_{1}^{1} \\
y_{2}^{1}
\end{array}\right]=\left[\begin{array}{ll}
h_{11} & h_{12} \\
h_{21} & h_{22}
\end{array}\right]\left[\begin{array}{l}
x_{1} \\
x_{2}
\end{array}\right]+\left[\begin{array}{l}
n_{1}^{1} \\
n_{2}^{1}
\end{array}\right]} \\
& {\left[\begin{array}{l}
y_{1}^{2} \\
y_{2}^{2}
\end{array}\right]=\left[\begin{array}{ll}
h_{11} & h_{12} \\
h_{21} & h_{22}
\end{array}\right]\left[\begin{array}{c}
-x_{2}^{*} \\
x_{1}^{*}
\end{array}\right]+\left[\begin{array}{l}
n_{1}^{2} \\
n_{2}^{2}
\end{array}\right]}
\end{aligned}
$$

$\mathrm{Y}$ adalah matriks pada sinyal yang diterima pada receiver. Sedangkan $H$ adalah matriks kanal MIMO, $n$ adalah noise yang terjadi akibat kanal wireless, dan $x$ adalah informasi yang dikirimkan. Persamaan 1 adalah persamaan sinyal yang diterima pada timeslot pertama dan Persamaan 2 untuk timeslot yang kedua. Pada receiver, untuk mendapatkan kembali sinyal yang asli, diperlukan decoder STBC. Adanya matriks $H$ yang dibentuk dari estimasi nilai $h_{\mathrm{ij}}$ pada kanal transmisi berfungsi untuk mendapatkan kembali sinyal independent sebagaimana yang dikirim dari sisi pengirim. Dengan demikian, sinyal transmisi $(x)$ didapatkan dengan mengalikan inverse $H$ dengan sinyal pada receiver $(y)$. Jika pada transmitter $[Y]=[H]^{*}[X]$, maka pada receiver $[X]=(I N V[H]) *[Y]$.

Jika persamaan 1 dan 2 untuk timeslot 1 dan 2 digabungkan, maka persamaannya akan menjadi:

$$
\left[\begin{array}{l}
y_{1}^{1} \\
y_{2}^{1} \\
y_{1}^{2^{*}} \\
y_{2}^{2^{*}}
\end{array}\right]=\left[\begin{array}{cc}
h_{11} & h_{12} \\
h_{21} & h_{22} \\
h_{12}^{*} & -h_{11}^{*} \\
h_{22}^{*} & -h_{21}^{*}
\end{array}\right]\left[\begin{array}{l}
x_{1} \\
x_{2}
\end{array}\right]+\left[\begin{array}{l}
n_{1}^{1} \\
n_{2}^{1} \\
n_{1}^{2^{*}} \\
n_{2}^{2^{*}}
\end{array}\right]
$$
adalah:

Dengan mendefinisikan matriks channel MIMO $H$ 


$$
H=\left[\begin{array}{cc}
h_{11} & h_{12} \\
h_{21} & h_{22} \\
h_{12}^{*} & -h_{11}^{*} \\
h_{22}^{*} & -h_{21}^{*}
\end{array}\right]
$$

Untuk mencari $\left[\begin{array}{l}x_{1} \\ x_{2}\end{array}\right]$, maka harus dicari terlebih dahulu inversi dari $H$. Dengan inversi pseudo dapat didefinisikan sebagai:

$$
H^{+}=\left(H^{H} H\right)^{-1} H^{H}
$$

dengan definisi bahwa,

$$
\left(H^{H} H\right)=\left[\begin{array}{cc}
\left|h_{11}\right|^{2}+\left|h_{21}\right|^{2}+\left|h_{12}\right|^{2}+\left|h_{22}\right|^{2} & 0 \\
0 & \left|h_{11}\right|^{2}+\left|h_{21}\right|^{2}+\left|h_{12}\right|^{2}+\left|h_{22}\right|^{2}
\end{array}\right]
$$

Karena matriks di atas merupakan matriks diagonal, maka jika diinversi, menjadi:

$$
\left(H^{H} H\right)^{-1}=\left[\begin{array}{cc}
\frac{1}{\left|h_{11}\right|^{2}+\left|h_{21}\right|^{2}+\left|h_{12}\right|^{2}+\left|h_{22}\right|^{2}} & 0 \\
0 & \frac{1}{\left|h_{11}\right|^{2}+\left|h_{21}\right|^{2}+\left|h_{12}\right|^{2}+\left|h_{22}\right|^{2}}
\end{array}\right]
$$

Estimasi simbol yang ditransmisikan dapat dituliskan dengan:

$$
\left[\begin{array}{l}
\hat{x_{1}} \\
x_{2}
\end{array}\right]=\left(H^{H} H\right)^{-1} H^{H}\left[\begin{array}{l}
y_{1}^{1} \\
y_{2}^{1} \\
y_{1}^{2^{*}} \\
y_{2}^{2^{*}}
\end{array}\right]
$$

Pada MIMO Matriks A, Code bekerja dengan sepasang simbol pada satu waktu dan membutuhkan 2 periode waktu untuk mentransmisikan 2 simbol. Sehingga besar data rate yang dihasilkan sama dengan data yang memasuki encoder namun performa error sistem meningkat. Sistem dengan performa SNR yang tinggi, peningkatan pada error rate didapat sebagai hasil dari penggunaan Space-Time code dapat ditukar dengan kapasitas lebih besar dengan penggunaan modulasi dengan orde lebih tinggi.

\section{OFDM}

OFDM adalah teknik transmisi yang sangat kuat. OFDM berdasarkan prinsip transmisi secara simultan banyak frekuensi orthogonal narrow-band, sering juga disebut OFDM subcarrier atau subcarrier. Jumlah subcarrier sering dinyatakan dengan $N$. Frekuensifrekuensi ini saling orthogonal satu sama lain yang (dalam teori) mengeliminasi interferensi antara channel. Masing-masing channel frekuensi dimodulasi dengan berbagai macam modulasi yang mungkin. Frekuensi bandwidth yang terkait dengan setiap channel ini akan jauh lebih kecil jika dibandingkan total bandwidth yang diduduki oleh satu modulasi. Hal ini dikenal sebagai Single Carrier (SC). Sebuah waktu simbol data $N$ kali lebih lama, dengan OFDM menyediakan resistansi multipath yang jauh lebih baik.

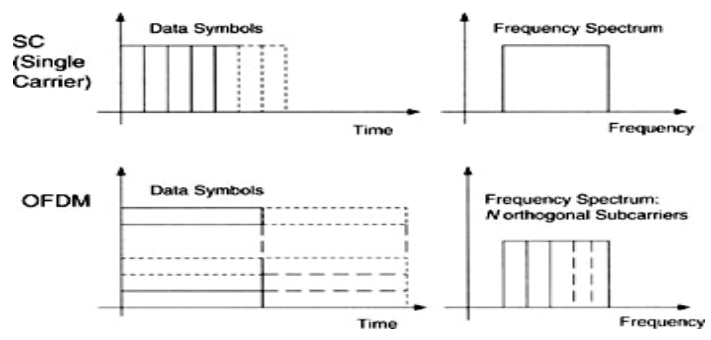

Gambar 3. Representasi Waktu dan Frekuensi dari SC dan OFDM. Dalam OFDM, $N$ data simbol ditransmisikan secara simultan pada $N$ orthogonal subcarriers.

\section{Metode Hybrid}

Transmisi dengan metode hybrid ini menggunakan tiga buah antena Tx dan Rx serta dua buah relay station. Berikut skema metode hybrid yang dimaksud. Metode ini menggunakan prinsip STBC.

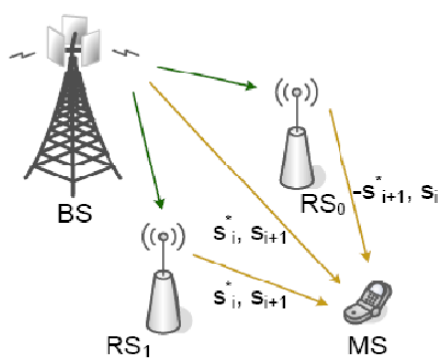

Gambar 4. Transmisi Metode Hybrid.

Sebuah pemilih skema forwarding memilih sebuah skema forwarding untuk transmisi. Blok Amplify and Forward (AF) menguatkan data yang diterima dari pemilih skema forwarding, jika skema AF dipilih. Blok Decode and Forward (DF) men-decode dan mengencode data yang diterima dari pemilih skema forwarding, jika skema DF dipilih [10].

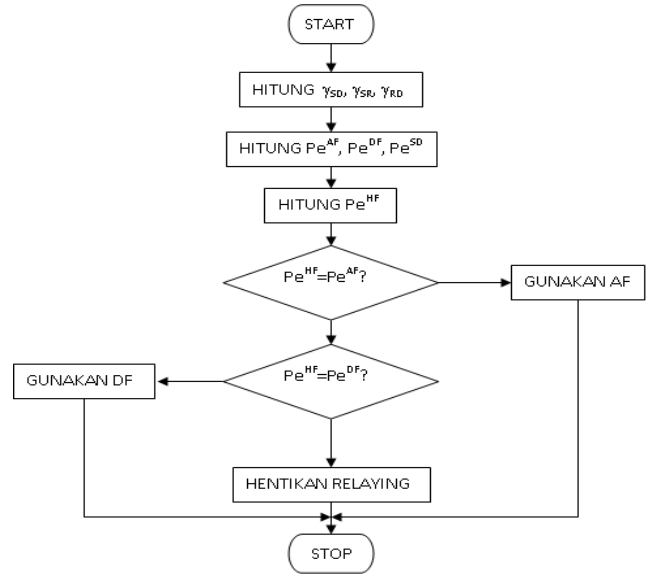

Gambar 5. Flow Chart Skema Pemilihan AF atau DF.

Untuk membuat suatu perbandingan antara AF, DF, dan transmisi direct, data rates dan daya transmisi total dijaga sama untuk transmisi direct dan relaying. Untuk skema transmisi direct, BPSK digunakan dan terminal sumber mentransmisikan simbol di kedua time slot, odd dan even. Untuk skema relay, QPSK digunakan. Terminal relay menghitung bit error probability tiap subcarrier untuk masing-masing AF, DF, dan skema transmisi direct. 
Terminal relay diberitahukan SNR dari simbol di setiap subcarrier dalam link S-D, R-D, dan S-R. Pengukuran SNR ini di kembalikan ke terminal relay pada virtual diversity channel. S, R, dan D menyatakan terminal sumber, terminal relay, dan terminal tujuan. Karena itu, S-D merepresentasikan link dari terminal sumber ke terminal tujuan, R-D merepresentasikan link dari terminal relay ke terminal tujuan, dan S-R merepresentasikan link dari terminal sumber ke terminal relay.

Terminal relay mengkalkulasikan bit error probability tiap subcarrier untuk masing-masing $A F$, $D F$, dan skema transmisi direct. Asumsikan masing masing probabilitas tersebut direpresentasikan oleh $P_{e}^{A F}$ , $P_{e}^{D F}, \operatorname{dan} P_{e}^{S D} . \quad P_{e}^{A F}$ dapat diberikan dengan persamaan sebagai berikut:

$$
P_{e}^{A F}=Q\left(\sqrt{\gamma_{s}^{A F}}\right), \gamma_{s}^{A F}=\frac{\left(\gamma_{S D}+\frac{\gamma_{S R} \gamma_{R D}}{1+\gamma_{S R}}\right)^{2}}{\gamma_{S D}+\frac{\gamma_{S R} \gamma_{R D}}{1+\gamma_{S R}}+\frac{\gamma_{S R} \gamma_{R D}^{2}}{\left(1+\gamma_{S R}\right)^{2}}}
$$

di mana $Q($.$) merepresentasikan Gaussian tail$ probability function. $\quad P_{e}^{D F}$ dinyatakan dengan persamaan :

$P_{E}^{A F}=\left\{\begin{array}{c}\left(1-Q\left(\sqrt{\gamma_{S R}}\right)\right) Q\left(\sqrt{\gamma_{S R}+\gamma_{R D}}\right)+Q\left(\frac{\sqrt{\left(\gamma_{S D}-\gamma_{R D}\right)^{2}}}{\gamma_{S D}+\gamma_{R D}}\right) Q\left(\sqrt{\gamma_{S R}}\right), j i k a \cdot \gamma_{S D}-\gamma_{R D} \geq 0 \\ \left(1-Q\left(\sqrt{\gamma_{S R}}\right)\right) Q\left(\sqrt{\gamma_{S R}+\gamma_{R D}}\right)+\left(1-Q\left(\frac{\sqrt{\left(\gamma_{S D}-\gamma_{R D}\right)^{2}}}{\gamma_{S D}+\gamma_{R D}}\right)\right) Q\left(\sqrt{\gamma_{S R}}\right), j i k a \cdot \gamma_{S D}-\gamma_{R D}\langle 0\end{array}\right.$

$P_{e}^{S D}$ diberikan oleh persamaan:

$$
P_{e}^{S D}=Q\left(\frac{\sqrt{\gamma_{S D}+\gamma_{R D}}}{2}\right)
$$

Untuk sebuah kombinasi dari hybrid forwarding dan transmisi direct, bit error probability minimum dihitung dengan persamaan :

$$
P_{e}^{H F}=\min \left(P_{e}^{A F}, P_{e}^{D F}, P_{e}^{S D}\right)
$$

Pada persamaan-persamaan di atas, $\gamma_{S R}, \gamma_{S D}$ dan $\gamma_{R D}$ merepresentasikan SNR dari subcarrier yang diberikan pada link S-R, S-D, dan R-D.

Untuk subcarrier yang diberikan, terminal relay menyeleksi skema forwarding yang menyediakan bit error probability minimum sebagai berikut:

- Jika $P_{e}^{H F}=P_{e}^{A F}$, maka terminal relay akan memilih AF untuk subcarrier.

- Jika $P_{e}^{H F}=P_{e}^{D F}$, maka terminal relay akan memilih DF untuk untuk subcarrier.

- Jika $P_{e}^{H F}=P_{e}^{S D}$, maka terminal relay akan menghentikan relaying subcarrier.
III.

\section{PEMOdELAN TRANSMISI MULTIHOP Mobile Wimax Dengan Metode HYBRID}

Simulasi ini dibuat dengan menggunakan perangkat lunak Simulink/MATLAB 7.6.0 (R2008a) dengan sistem operasi Windows XP Professional service pack 2.

Berikut ini adalah gambaran umum simulasi yang telah dibuat.

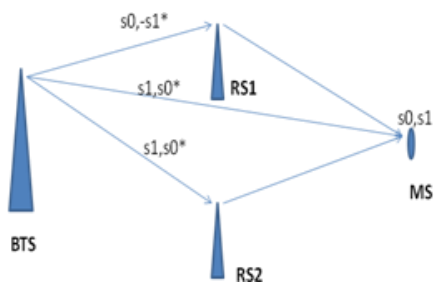

Gambar 6. Gambaran Umum Simulasi yang Dibuat.

Pada Gambar 6, jaringan multihop, yang menggunakan dua atau lebih hop untuk mentransmisikan data dari source ke destination, dengan menggunakan metode transmisi hybrid dapat dilihat pada link yang menghubungkan BTS dengan MS dengan urutan BTS-RS1-MS maupun BTS-RS2-MS. Pada Gambar 6, link relay adalah BTS-RS1 dan BTSRS2. Sedangkan link access adalah RS1-MS, BTS-MS, dan RS2-MS.

Pada jaringan tersebut, relay station digunakan sebagai amplifier maupun decoder dan encoder. Relay station ini diperlukan untuk membantu mentransmisikan data dari BTS ke MS atau sebaliknya dalam kondisi kanal yang buruk. Kondisi yang dimaksud yaitu letak MS yang jauh atau dipinggiran cell sehingga untuk memperoleh kualitas layanan yang baik, maka ditambahkanlah relay station ini. Walaupun kondisi tersebut buruk, namun transmisi direct antara BTS dengan MS tetap terjadi.

Simulasi yang dibuat adalah simulasi transmisi pada PHY layer Multihop mobile WiMAX dengan metode hybrid. Simulasi ini terdiri dari lima bagian utama, yaitu transmitter, channel 1, relay station, channel 2, dan receiver. Simulasi ini dibuat dengan memodifikasi simulasi atau demo yang ada pada matlab, yaitu "IEEE@ 802.16-2004 OFDM PHY Link, Including Space-Time Block Coding". Modifikasi yang dilakukan ada pada penggunaan STBC dari dua antena transmitter menjadi tiga antena transmitter. Untuk itu, di sisi receiver juga perlu dilakukan pengubahan dalam blok STBC combiner. Selain itu, ditambahkan juga dua buah blok yang masing-masing mewakili satu buah relay station.

Pada blok relay station, skema pemilihan forwarding seperti yang dijelaskan sebelumnya tidak digunakan. Hal ini dikarenakan skema tersebut berjalan secara otomatis sehingga untuk melihat perbedaan masing-masing forwarding cukup sulit. Oleh karena itu, skema yang seharusnya digunakan diganti dengan menggunakan suatu konstanta yang dapat memilih skema forwarding mana yang aktif. 
IV.

ANALISIS Dan Hasil Simulasi

Parameter-parameter yang diatur sebelum simulasi dijalankan yaitu besarnya channel bandwidth sebesar 3,5 MHz, jumlah simbol OFDM per burst sebanyak empat simbol, faktor cyclic prefix (CP) sebesar 1/8, dan low SNR threshold for rate control pada 4, 10, 12, 19, 22 , dan $28 \mathrm{~dB}$.

\section{A. Kinerja Sistem Ketika RS1 dan RS2 Mengaktifkan AF}

RS1 diatur agar yang aktif adalah blok AF (Amplify and Forward), di mana hanya berisi blok gain. Begitu pula dengan RS2, yang aktif hanya blok AF.

Selanjutnya, simulasi dijalankan dengan memvariasikan nilai SNR pada masing-masing channel AWGN, dengan besar SNR yang sama, agar dapat dilihat perbandingan antara SNR pada receiver dengan BER, dan SNR pada receiver dengan throughput. Hasilnya dapat dilihat pada Gambar 7.
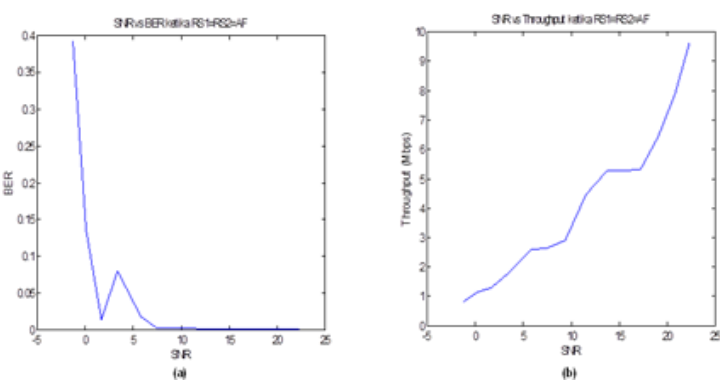

Gambar 7. Performansi Simulasi Pertama.

Gambar 7 (a), secara umum ketika SNR naik, maka nilai BER mengecil sehingga semakin banyak data yang diterima dan semakin sedikit data yang error.

Untuk Gambar 7 (b) terlihat bahwa semakin besar SNR maka semakin besar pula throughput-nya. Hal ini berkaitan dengan menurunnya nilai BER sehingga banyaknya data yang dikirim (bit) sedikit ada yang error ketika sampai di penerima. Besarnya throughput yang diperoleh ketika SNR pada AWGN channel diatur $21 \mathrm{~dB}$, nilai SNR di receiver sebesar $17,21 \mathrm{~dB}$, adalah 5,301836 Mbps.

Pada kondisi ini, Relay Station berperan sebagai amplifier yang hanya me-relay sinyal data yang dikirimkan oleh OFDM transmitter. Selanjutnya, sinyal ini akan dikirimkan kembali oleh relay sation ke OFDM receiver dan akan diproses lebih jauh di receiver.

Selanjutnya, data grafik konstelasi diambil dengan besar SNR pada masing-masing blok AWGN channel diatur sebesar $21 \mathrm{~dB}$. Diagram konstelasinya dapat dilihat pada Gambar 8.

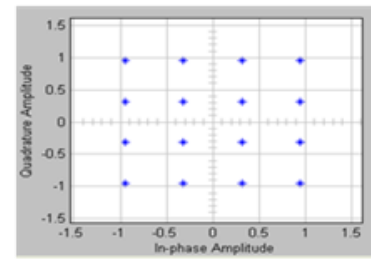

(a)

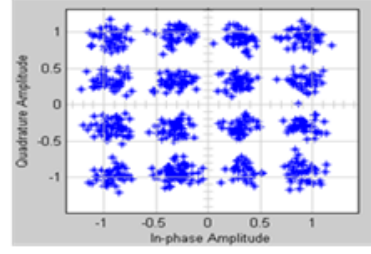

(b)
Gambar 8. Konstelasi Simulasi Pertama.

\section{B. Kinerja Sistem Ketika AF Aktif pada RS1 dan DF Aktif pada RS2}

Selanjutnya, simulasi kedua dilakukan dengan mengatur RS1 agar mengaktifkan AF dan RS2 mengaktifkan DF. Sama seperti sebelumnya, simulasi ini juga dilakukan dengan memvariasikan nilai SNR pada masing-masing AWGN channel.
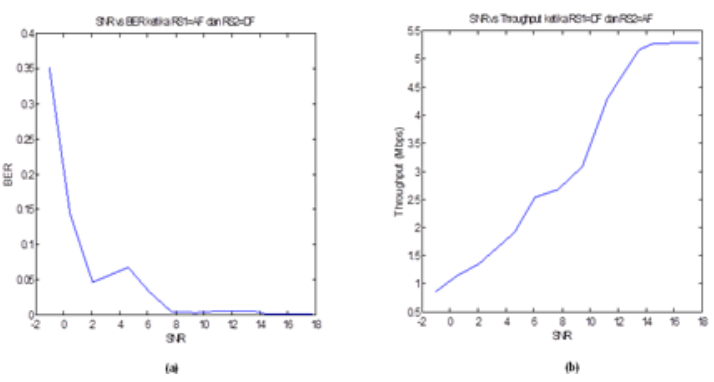

Gambar 9. Performansi Simulasi Kedua.

Gambar 9 (a) memperlihatkan bahwa ketika SNR naik maka BER akan turun meskipun ada yang nilai BER-nya naik. Pada Gambar 9 (b) dapat dilihat besarnya throughput semakin meningkat seiring dengan meningkatnya SNR karena nilai BER juga menurun. Gambar 10 menunjukkan diagram konstelasinya.

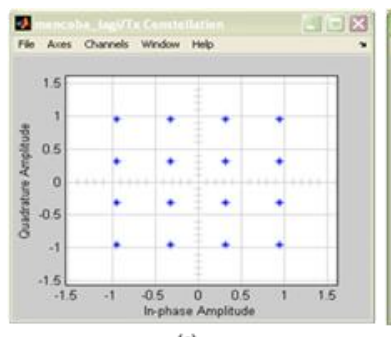

(a)

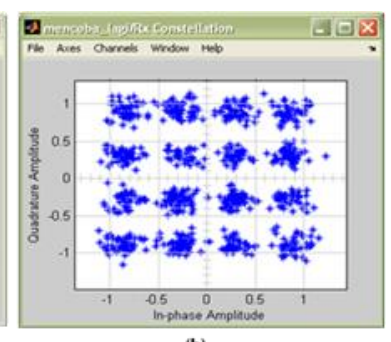

(b)
Terlihat bahwa konstelasi yang terbentuk pada receiver menyerupai konstelasi pada transmitter sehingga dapat dipastikan bahwa transmisi telah berhasil dilakukan dengan baik.

\section{Kinerja Sistem Ketika DF Aktif pada RS1 dan AF Aktif pada RS2}

RS1 diatur agar mengaktifkan DF, sedangkan RS2 diatur agar mengaktifkan AF. Untuk melihat perbandingan SNR pada receiver dengan BER dan SNR pada receiver dengan throughput, maka AWGN channel diatur nilai SNR-nya.

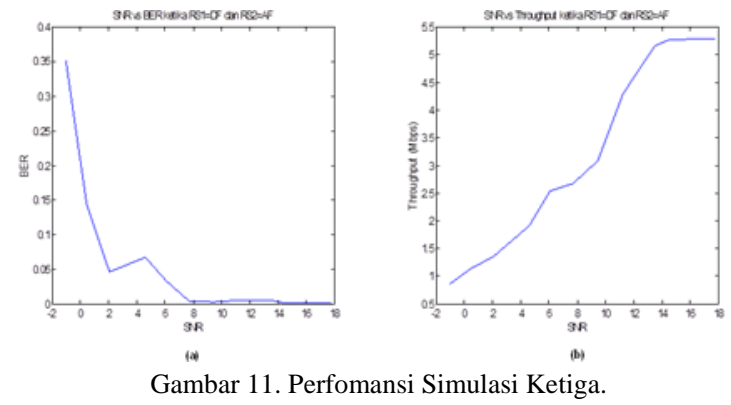

Dari Gambar 11 (a) dapat diketahui bahwa SNR yang semakin besar, maka BER semakin kecil. Sedangkan untuk Gambar 11 (b) semakin besar SNR maka semakin besar pula throughput-nya. Nilai-nilai 
yang ada pada Gambar 11 ternyata sama dengan nilainilai ketika RS1 mengaktifkan AF dan RS2 mengaktifkan DF. Hal ini dikarenakan RS1 dan RS2 memiliki karakteristik yang sama sehingga ketika mode forwarding antara dua relay station ini ditukar tidak akan ada perubahan data yang diterima oleh receiver.

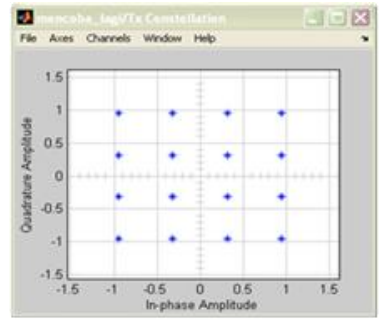

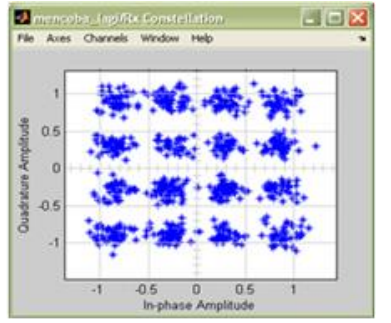

(b)
Gambar 12. Konstelasi Simulasi Ketiga.

Gambar 12 menjelaskan diagram konstelasi yang terjadi, di mana modulator yang aktif adalah 16-QAM dengan rate $1 / 2$. Dengan melihat diagram konstelasi tersebut transmisi dapat dikatakan berhasil dengan baik.

\section{Kinerja Sistem Ketika RS1 dan RS2 Mengaktifkan DF}

RS1 dan RS2 masing-masing mengaktifkan Decode and Forward (DF). Lalu untuk mengetahui perbandingan antara SNR pada receiver dengan BER dan SNR pada receiver dengan throughput, maka nilai SNR pada masing-masing AWGN channel divariasikan.

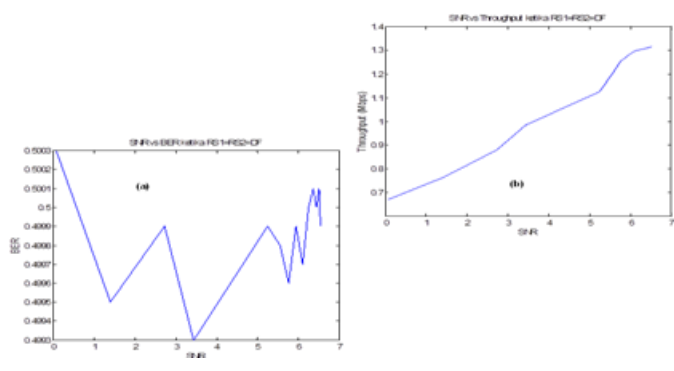

Gambar 13. Performansi Simulasi Keempat.

Hasil yang diperoleh dalam simulasi ini berbeda dari simulasi sebelumnya. Pada Gambar 13 (a), semakin besar SNR pada receiver ternyata BER yang diperoleh tidak jauh berubah yaitu berkisar 0,5 yang merupakan nilai BER yang sangat besar. Ini merupakan suatu loss yang sangat besar. Selain itu, ketika SNR pada AWGN channel diatur semakin besar ternyata SNR pada receiver tidak meningkat jauh. Terlihat bahwa noise sangat besar sehingga nilai SNR turun jauh.

Apabila kita melihat Gambar 13 (b), dapat dikatakan bahwa ketika SNR naik maka throughput juga akan naik. Namun, kenaikan SNR tidak terlalu jauh. Begitu juga dengan kenaikan throughput.

Pada kondisi ini, disadari bahwa relay station sangat mempengaruhi unjuk kerja sistem dan sangat merugikan. Karena pada kondisi ini kedua relay station mengaktifkan DF, maka seperti ada kekacauan pada data yang diterima oleh receiver, seakan-akan data menjadi bertumpuk dan akhirnya pada receiver yang diterima hanya setengah dari data yang dikirimkan.

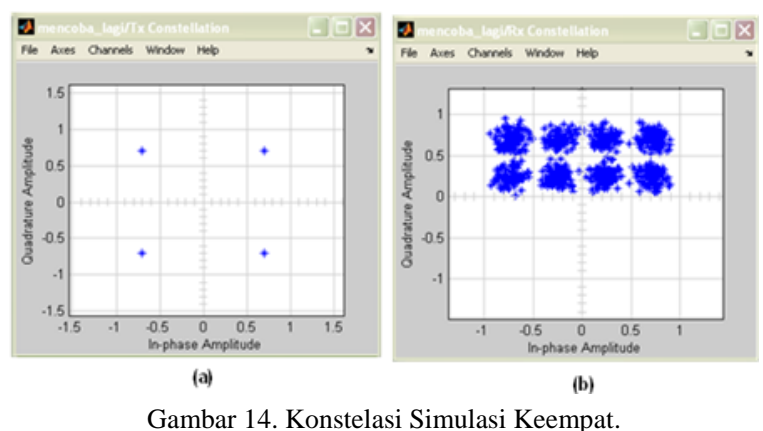

Gambar 14 menunjukkan konstelasi yang terjadi. Terlihat bahwa sistem ini tidak mentransmisikan data dengan baik karena perbedaan konstelasi di sisi pengirim dengan sisi penerima.

\section{KESIMPULAN}

Dari hasil simulasi dalam empat kondisi tersebut dan dari hasil analisis, maka dapat diambil kesimpulan sebagai berikut.

- Simulasi dengan kondisi RS1 dan RS2 sama-sama mengaktifkan mode forwarding Amplify and Forward (AF) menghasilkan unjuk kerja yang paling baik. Tercatat ketika SNR pada AWGN channel diatur masing-masing bernilai $21 \mathrm{~dB}$, SNR pada receiver diperoleh sebesar $17,21 \mathrm{~dB}$, data yang diterima sebanyak 5306000 bit, data yang error sebanyak 4164 bit, dan throughput yang diperoleh sebesar 5.301836 Mbps.

- Simulasi dengan kondisi RS1 mengaktifkan AF dan RS2 mengaktifkan DF memperoleh unjuk kerja yang sama dengan simulasi ketika kondisi RS1 mengaktifkan DF dan RS2 mengaktifkan AF. Hal ini dapat dilihat dari grafik perbandingan SNR vs BER dan SNR vs Throughput yang sama pada dua kondisi tersebut. Begitu pula dengan konstelasinya. Secara kuantitatif juga diperlihatkan kesamaannya. Contohnya ketika SNR di AWGN channel diatur sebesar $21 \mathrm{~dB}$, SNR pada receiver sebesar 15,56 $\mathrm{dB}$, data yang diterima sebanyak 5284000 bit, data yang error sebanyak 5389 bit, dan besarnya throughput sebesar 5,278611 Mbps.

- Simulasi dengan kondisi RS1 dan RS2 sama-sama mengaktifkan DF adalah simulasi dengan unjuk kerja atau hasil yang paling buruk. Tercatat ketika SNR pada AWGN channel diatur sebesar $21 \mathrm{~dB}$, SNR pada receiver didapat sebesar 6,368 dB, banyaknya data yang diterima sebanyak 2615000 bit, data yang error sebanyak 1307000 bit, dan throughput yang diperoleh sebesar 1,308 Mbps.

- Dari simulasi yang dilakukan, penggunaan relay station pada transmisi metode hybrid ini sangat dihindari kondisi di mana RS1 dan RS2 sama-sama mengaktifkan DF karena performa yang buruk dan sangat merugikan.

\section{Daftar Pustaka}

[1] Local and metropolitan area networks; Part 16: Air Interface for Fixed Broadband Wireless Access, IEEE Std. 802.16, 2004.

[2] Local and metropolitan area networks; Part 16: Air Interface for Fixed Broadband Wireless Access Systems, Amendment 2: Physical and Medium Access Control Layers for Combined Fixed and Mobile Operation in Licensed Bands and Corrigendum 1, IEEE Std. 802.16e, 2005. 
[3] WiMAX Forum (2006) Mobile WiMAX - Part I: A Technical Overview and Performance Evaluation. [Online]. Available: http://www.wimaxforum.org/news/downloads/Mobile_WiMA X_Part1_Overview_and_Performance.pdf

[4] WiMAX Forum White Paper, "Mobile WiMAX - Part I: a technical overview and performance evaluation", March 2006.

[5] G. Nair, J. Chou, T. Madejski, K. Perycz, D. Putzolu, and J. Sydir, "IEEE 802.16 medium access control and service provisioning", Intel Technology Journal, vol. 3, iss. 3, pp. 216217, August 2004.

[6] (2007) Multiple Antenna System in WiMAX; an Introduction to MIMO, SAS and Diversity. [Online]. Available: www.airspan.com

[7] A. Salvekar, S. Sandhu, Q. Li, M. A. Vuong, X. Qian, "Multiple-Antenna Technology in WiMAX Systems, Intel
Technology Journal, vol. 08, iss. 03, pp. 229-240, August 2004.

[8] K. Sankar. (2009) Alamouti STBC with 2 receive antenna. [Online]. Available: http://www.dsplog.com/2009/03/15/alamouti-stbc-2-receiveantenna/

[9] I. K. Fu, W. H. Sheen, F. C. Ren,'Deployment and radio resource reuse in IEEE $802.16 \mathrm{j}$ multi-hop relay network in Manhattan-like environment", in Proc. 6 th ICICS, 2007, DOI: 10.1109/ICICS.2007.4449752, pp. 1-5

[10] B. Can, H. Yomo, E. Carvalho, K. Sivanesan, D. Y. Kim, M. D. Katz, D. S. Park, and S. K. Hong, "Hybrid Forwarding Apparatus and Method of Cooperative Relaying in An OFDM Network" U. S. Patent 7746 815, Jun. 29, 2010. 